\title{
A Critical Analysis of the Philosophical-Political Element of the Master-Slave Dialectic ${ }^{1}$
}

\author{
Matheus Pelegrino da Silva ${ }^{2}$
}

\begin{abstract}
The section "Lordship and Bondage" in Hegel's Phenomenology of Spirit offers us, through the criticism of slavery, some indications regarding Hegel's conception of human nature. In this paper some consequences of this conception for Hegel's political philosophy are identified and presented. The analysis shows problems may emerge when we analyze some fundamental Hegelian concepts - "recognition" and shows that some "men" - if we take into consideration the way these concepts were defined in the master-slave dialectic. In light of these problems it is pointed out that Hegel's political philosophy, and also his position regarding slavery, become less cogent and more susceptible to criticism. The last part of the text analyzes some consequences of problems related to the possibility of defining the concepts "recognition" and "men" in terms of Hegel's model of state.
\end{abstract}

KEYWORDS: Hegel. Master-slave dialectic. Recognition. State.

In the section "Independence and dependence of self-consciousness" of Hegel's Phenomenology of Spirit, the problem of slavery is usually presented in the following way: Two consciousnesses met, fought, and one of them was defeated and became the slave of the other. After a period of forced work the slave gets stronger and defeats his master, showing that slavery is a temporary condition. The master-slave dialectic teaches us through this story that the relation of domination and submission is not a proper relation of human beings, and that this relation ultimately starts a process which always results in the liberation of the slave.

The above proposed way of understanding the master-slave dialectic, which can be attributed to Alexandre Kojève's remarks at the beginning of his commentary on Hegel's Phenomenology $y^{3}$, has had great influence on subsequent interpretations of this section of Hegel's book. In opposition to this interpretative hypothesis, various commentaries have been written which

\footnotetext{
${ }^{1}$ http://dx.doi.org/10.1590/S0101-31732015000300002

${ }^{2}$ Doctoral student in the graduate progam in philosophy at UNISINOS. Financial support: CAPES. E-mail: mathpelegrino@hotmail.com

${ }^{3}$ See KOJÈVE, Alexandre. Introduction à la lecture de Hegel. Paris: Gallimard, 2000, p. 32-34.
} 
indicate with sufficent clearness and rigor that such an interpretation does not correspond to what is presented in the text of the Phenomenology of Spirit. ${ }^{4} \mathrm{We}$ are therefore brought to the question which we will attempt to answer through a reading of the section in the Phenomenology dealing with the master-slave dialectic: "[...] what is wrong about the enslavement of an individual, why is it not correct?"

In the present text we aim to indicate the answer to this question, showing that Hegel's main argument against slavery is not the one that maintains that the master will be defeated by his slave, who has strengthened himself through hard work and can now win the fight. The main argument indicates that the mistake regarding slavery is related to the way each individual understands himself, that is, how each individual thinks so as to know himself. As we present Hegel's argument against slavery, we will be able to point out how his reading of the relation of domination and submission involves, at its foundation, a specific conception concerning the nature of human beings and human relations. This conception will be an essential and determinant element of his political philosophy and of his conception of the relations between the individual and the state. After concluding the exposition of this relation, we will indicate some problems in the way Hegel deals with the theme of recognition, specifically in connection with his criteria for deciding what is relevant in order for recognition to occur. At the end of the article we will recapitulate some of the results obtained, in order to indicate the problems that emerge in regard to Hegel's political philosophy when the basis of the fundamental concepts of "recognition" and "men" are investigated.

A good starting point arises from the analysis of the way the parameters for recognition are described in the following passage of the Phenomenology:

The middle term is self-consciousness which splits into the extremes; and each extreme is this exchanging of its own determinateness and an absolute transition into the opposite. Although, as consciousness, it does indeed come out of itself, yet, though out of itself, it is at the same time kept back within itself, is for itself, and the self outside it, is for $i t$. It is aware that it at once is, and is not, another consciousness, and equally that this other is for itself only when it supersedes itself as being for itself, and is for itself only in the being-for-self of the other. Each is for the other the middle term,

\footnotetext{
${ }^{4}$ See, among others, the works of Labarrière, Jarczyk, and Williams. LABARRIÈRE, Pierre-Jean; JARCZYK, Gwendoline. Les premiers combats de la reconnaissance. Paris: Aubier - Montaigne, 1987, p. 133. WILLIAMS, Robert R. Recognition: Fichte and Hegel on the Other. New York: State University of New York, 1992, p. 181.
} 
through which each mediates itself with itself and unites with itself; and each is for itself, and for the other, an immediate being on its own account, which at the same time is such only through this mediation. They recognize themselves as mutually recognizing one another. ${ }^{5}$

According to this text there is always recognition when one consciousness, an individual, observes as its similar the other that is its similar. Since one consciousness states that the other consciousness is its similar and recognizes this other consciousness as such, in order for an effective recognition to come to exist it is necessary that the other consciousness does indeed behave in the same way, recognizing the first consciousness as its similar.

There is another excerpt in the Phenomenology of Spirit, regarding the moment when Hegel deals with the notion of recognition in order to analyze the relation between a master and a slave, which also contributes to explain how we should understand the use of the term "recognition": "But for recognition [, the] proper [one,] the moment is lacking, that what the lord does to the other he also does to himself, and what the bondsman does to himself he should also do to the other. The outcome is a recognition that is one-sided and unequal". ${ }^{6}$ We can see in this passage Hegel's concern to indicate that recognition is not always the recognition that occurs in the form presented in the above quoted excerpt from the Phenomenology. When the consciousnesses do not observe each other as similar, the recognition that a consciousness can achieve is always a recognition that it will achieve observing itself, i.e., it is "one-sided", and this recognition takes place through another being that is taken as different and thus "unequal". Therefore, at this moment we do not have an example of proper recognition, of full recognition, but only of an incomplete one.

By reading another excerpt in the same section, that will end up showing itself as the key to understanding Hegel's criticism about slavery, we find that the use of the terms "certainty" and "truth" qualify the recognition that a consciousness has of itself. Hegel asserts the following: "Each is indeed certain of its own self, but not of the other, and therefore its own self-certainty still has no truth. For it would have truth only if its own being-for-self had

\footnotetext{
${ }^{5}$ HEGEL, G. W. F. Phenomenology of Spirit. Translation by A. V. Miller. Oxford: Oxford University Press, 1977. Paragraph 184. From now on we will refer to this book with the abbreviation PS, followed by the number of the paragraph.
}

${ }^{6}$ PS 191. 
confronted it as an independent object". 7 The "truth" for Hegel, in opposition to "certainty", in this context, is characterized as a certainty which the subject has and that is confirmed by the world, confirmed by "an independent object". A self-consciousness has a certainty, and not the truth, of the fact that it is a self-consciousness, since it did not find anything in the world that would confirm its certainty that it is a self-consciousness. Vaz's commentary follows this path when he states that in human's world "[...] the consciousness truly makes its experience as a self-consciousness because [here] the object that is the mediator for its recognizing itself is not the indifferent object of the world, but is itself [the consciousness] in its being-other: it is another selfconsciousness". ${ }^{8}$ When they are in a relation of domination and submission, none of the consciousnesses truly knows itself, since the relation of the consciousnesses develops itself in such a way that one of the consciousnesses always sees the other as a different being, as non-similar. The master sees the slave as different from him, since the slave, contrary to the master, is not free. In the same way, the slave cannot see the master in any other way other than as different, since the slave sees himself as an individual that cannot have freedom, while the master is someone that has freedom.

The two consciousnesses, when they met for the first time, brought with them some truth, the truth that they are beings capable of dominating the objects of the world. This truth was obtained by them when they watched themselves acting in the world and changing it. Each of the consciousnesses confirmed its certainty as a dominator being through watching the dominated object that confirmed this certainty. However, this truth concerns the fact that consciousnesses are able to dominate objects of the world, and not the fact that they are able to dominate everything that exists in the world. The consciousness lives in a situation where its certainty of existing as a being, who is able to dominate everything, is constantly questioned, so that when the consciousness dominates an object it confirms one more time the certainty that it has about itself. However, as the consciousness consumes the dominated object, the truth that it has of itself as dominator is dissolved and the consciousness returns to its subjective certainty. The consciousness that aims to affirm itself as dominator lives in a world which frequently casts doubt on its certainty. The recognition that it achieves of being a dominator through the dominated object is constantly dissolved, since when it dominates the

${ }^{7}$ PS 186.

${ }^{8}$ VAZ, Henrique C. de Lima. Senhor e escravo: uma parábola da filosofia ocidental. Revista Sintese, s. 1., n. 21, p. 17, 1980. 
object, the consciousness consumes it and loses the confirmation of being the dominator of the object that it has obtained.

It is with the introduction of the slave into the relation that the dominator consciousness has with the world that it will be able, finally, to arrive at the truth that it is the dominator. When the master interposes the slave between himself and the world, the master compels the slave to bring him the objects of the world; the master becomes free from the world, and his certainty as a dominator being is no longer put into doubt with the consumption of the object, since he has a slave that provides new objects to be consumed.' Through the interposition of the slave between him and the things in the world, the master can finally free himself from the objects he had and that at every instant cast doubt on his condition of dominator. Following this interpretation, Hegel asserts:

For the lord, on the other hand, the immediate relation becomes through this mediation [the mediation done by the slave] the sheer negation of the thing, or the enjoyment of it. What desire failed to achieve, he succeed in doing, viz. to have done it with the thing altogether, and to achieve satisfaction in the enjoyment of it. Desire failed to do this because of the thing's independence; but the lord, who has interposed the bondsman between it and himself, takes to himself only the dependent aspect of the thing and has the pure enjoyment of it. The aspect of its independence he leaves to the bondsman, who works on it. ${ }^{10}$

The master will also obtain the truth about the certainty that he is the dominator, because his dominion over the slave is not exercised in the same way as his dominion over other objects. In dominating the slave, the master does not destroy him. He allows the slave to live, under the condition that he frees the master from the necessity of going to the world in order to confirm his certainty through the domination of the objects of the world. The domination of the slave is of a different kind from that which has occurred in relation to the other objects of the world. The truth of the certainty that the master has about himself

\footnotetext{
${ }^{9}$ This argument belongs in part to Pinkard, since he notes that the introduction of the slave into the relation that the master has with the world has the capacity to free the master from the necessity of going to the world to get the objects which confirm his certainty as the dominator consciousness. Our argument deviates from his, because he understands that the fight between the consciousnesses could have originated in the interest that both consciousnesses could have in interposing a slave in their relation with the world. Cf. PINKARD, Terry. Hegel's Phenomenology: the sociality of reason. Cambridge: Cambridge University Press, 1998, p. 50-52.
}

${ }^{10}$ PS 190. 
as a dominator is not dissolved when he dominates the object (the slave). Now the dominated object will continue to exist, and even so, it will exist only as a dominated object, and not for having survived the attempt of domination.

It is important to clarify something about the nature of the truth that the master obtains through the slave, since we have the following remark by Hegel: "In this recognition the unessential consciousness [the slave] is for the lord the object, which constitutes the truth of his certainty of himself. But it is clear that this object does not correspond to its Notion". ${ }^{11}$ Here we can see Hegel's concern to point out that the truth obtained by the master, through his relation with the slave, is not a full truth, a truth obtained in accordance with the concept of the subjects involved, or, in other words, with their true nature. When the master discovers the truth, that he is independent of everything, he does this by means of the slave; he obtains this certainty recognizing himself in an object, the slave, that is not being observed in accordance with his "Notion", his concept, the concept of a free consciousness. Because the consciousness that is the slave is observed as an object, and not as a consciousness, the master obtains a truth: that he is free in relation to the world. As this truth is obtained through a mistaken conception of the slave, a conception that observes the slave as an object and not as a consciousness, this truth is transitory. It does not have a foundation in the concept of the object, but only in the current manifestation of the consciousness that is a slave.

What was expressed above is the argument against slavery in the section "Independence and dependence of self-consciousness". To summarize, the following can be asserted: the relation of lordship and bondage is not a proper relation, a correct relation, since from it results a situation in which individuals do not know the truth regarding what they are. If they knew what they really are, if their knowledge was in harmony with their concept, they would recognize other individuals as similar, and they would not enslave these individuals. When one individual enslaves another, he denies freedom to the other and at the same time denies himself the possibility of truly knowing himself. ${ }^{12}$

\footnotetext{
${ }^{11}$ PS 192.

${ }^{12}$ With regard to how persuasive this argument against slavery is, it is worth quoting a remark by Allen Wood: "Hegel's argument shows only that dominating others is not the way to achieve selfcertainty as a free being. Hegel's argument gives me no reason for respecting rights of others if I happen to prefer freedom in the ordinary sense. Dominion may even provide me with a semblance of self-certainty if my conception of free selfhood is sufficiently undeveloped that I still confuse the dominion over others with self-certainty afforded me through recognition by others". WOOD, Allen W. Hegel's ethical thought. Cambridge: Cambridge University Press, 1995, p. 92.
} 
By asserting that a consciousness will only know the truth about itself when it recognizes another consciousness as its similar, and when the consciousness recognizes all other consciousnesses as its similar, Hegel is committing himself to a specific mode of relation among individuals, namely, the relation in which each individual recognizes as his similar all the other individuals that are, according to the concept, similar to him. Here it is necessary to say that this is not a small commitment. Asserting this about the individuals will necessarily involve sustaining that the correct order of things is the one in which all individuals recognize themselves as similar. It will involve sustaining that a society will only be in accordance with the truth if in it all individuals recognize themselves as similar, and it will mean sustaining that a state will only be in accordance with the truth if in it all individuals recognize themselves as similar. We reach now the main point of our argument. Hegel has a certain conception of human relations, namely, that all individuals recognize themselves as similar; from this conception results, among other things, that when Hegel reflects about the state, he will need to conceive a state that, as the true expression of the state, harmonizes with the true expression of the individual. This is the hidden political-philosophical element in the dialectic of the master and slave in the Phenomenology of Spirit. By dealing with individual consciousnesses, Hegel ends up drawing some parameters about the model of state he shall conceive. It is not allowed, once it was established what the truth about the individuals is, to conceive another model of state except the one that is in accordance with a certain kind of relation that individuals should establish among themselves. The state, however ever it turns out to be, will always need to be, if it is intended to be the true way of manifesting the notion of state, a state where the individuals relate in such a way that they recognize themselves as similar. The state will never be allowed to have a characteristic that will make it impossible for individuals to fully accomplish recognition.

Making use of an essential extract from the Encyclopaedia of Philosophical Sciences, we will try to indicate in what way a certain conception of the individual actually conditions the way the state will be conceived. Taking into account the last paragraph of the section of the Encyclopaedia devoted to the subjective spirit, and the first paragraphs of the following section concerning the objective spirit, we will point out how a specific procedure for determining the way of conceiving the individual will concretely entail and establish the kind of state thought by Hegel. 
In the remark of paragraph 482, the last of the section on the subjective spirit, Hegel presents the way in which the concept "freedom" was comprehended throughout history. He points out that over a long period, and among many peoples, such a concept was not apprehended properly, as freedom was not attributed to all men, but only to few of them. ${ }^{13}$ It would be only with the arrival of Christianity that the notion of freedom would be modified in order to include all human beings as individuals that have this property. ${ }^{14}$ Taking that into account, Hegel claims that there can be a "knowledge" about freedom. In this case all men know that their essence, the essence of all men, is freedom, meaning that all men have freedom as one of their specific aspects: "[...] to be aware, that is, that men are aware of freedom as their essence, aim, and object". ${ }^{15}$ Freedom will stipulate what is right, what is the truth, about human beings: that human beings, all human beings, are (at least potentially) free beings, and that only if we conceive all human beings in such a way we will be able to obtain a "knowledge", and not only a "certainty", about what we, as human beings, really are. In this excerpt from the Encyclopaedia we find an elucidation, at least a partial one, of the defining elements of what the "concept" of "man" is.

Considering that men were characterized as having freedom as their essence and aim, the section on the objective spirit begins by dealing with the theme of the actualization of the aim of men: freedom. This essence, which is specific to men, will condition, as we will see, the way the state will be conceived. According to Hegel, men have a specific will, the "free will", whose aim is "[...] to realize [, to attain,] its concept, Liberty, in these externally objective aspects, making the latter a world moulded by the former, which in it is thus at home with itself, locked together with it". ${ }^{16}$ The nature of human

13 "Whole continents, Africa and the East, have never had this Idea, and are without it still. The Greeks and Romans, Plato and Aristotle, even the Stoics, did not have it. On the contrary, they saw that it is only by birth (as, for example, an Athenian or Spartan citizen), or by strength of character, education, or philosophy (- the sage is free even as a slave and in chains) that the human being is actually free." HEGEL, G. W. F. Encyclopaedia of Philosophical Sciences. Translation by W. Wallace. \$ 482, remark. Source: http://www.class. uidaho.edu/mickelsen/ToC/Hegel\%20-\%20Philosophy\%20of\%20Mind. htm. From this point forward we will refer to this edition of Hegel's Encyclopaedia of philosophical sciences with the abbreviation EPS, followed by the number of the paragraph.

${ }^{14}$ EPS, $\$ 482$, remark: "It was through Christianity that this Idea [freedom] came into the world. According to Christianity, the individual as such has an infinite value as the object and aim of divine love, destined as mind to live in absolute relationship with God himself, and have God's mind dwelling in him: i.e. man is implicitly destined to supreme freedom."

${ }^{15}$ EPS, $\$ 482$, remark.

${ }^{16}$ EPS, $\$ 484$. 
will, a reflex of his essence, which is to be a free being, conditions his behavior; it conducts men to behave in a specific way, searching for the attainment of their aim. This process, in turn, comprehends certain modes of relation among human beings, since the free will of each individual, in order to be attained, will need to be conducted in a specific way; it will be necessary that the singular individuals, owners of particular wills, form an alliance in order for a true attainment of the essence of human beings to occur. These alliances among men are necessary. We just need to remember that the truth about human beings will only be reached when all of them recognize themselves as free beings and, in fact, they all are free beings. Recognition is not possible if all that we have are some individuals that are actually free and that recognize all individuals as potentially free.

Following the text of the Encyclopaedia we find the indication of how the free will, the essence of all men, will be attained. In the outline below it is possible to notice that Hegel includes all the fundamental elements of his political philosophy, all constitutive elements of his Philosophy of Right:

The free will is:

(A) Itself at first immediate, and hence as a single being - the person: the existence which the person gives to its liberty is property. The Right as Right (law) is formal, abstract right.

(B) When the will is reflected into self, so as to have its existence inside it, and to be thus at the same time characterized as a particular, it is the right of the subjective will, morality of the individual conscience.

(C) When the free will is the substantial will, made actual in the subject and conformable to its concept and rendered a totality of necessity - it is the ethics of actual life in family, civil society, and State. ${ }^{17}$

For the purposes of the present analysis it is not necessary to detail each one of the spheres in which the free will manifests itself. What can be indicated is the concern Hegel shows in filling all the moments of the attainment of the state with the presence and orientation of the free will. ${ }^{18}$ The free will, product

\footnotetext{
${ }^{17}$ EPS, $\$ 487$.

${ }^{18}$ Following this line of thought we can quote the following excerpt: "All the aims of society and the State are the private aims of the individuals. But the set of adjustments, by which their duties come back to them as the exercise and enjoyment of right, produces an appearance of diversity: and this diversity is increased by the variety of shapes which value assumes in the course of exchange, though it remains intrinsically the same”. EPS, $₫ 486$, remark.
} 
of a certain conception of the human being's essence, works as the principle that conducts the whole model of the state and political philosophy.

Having made these points about the relation between the way to conceive the individual and Hegel's political thought, we can conclude that the master-slave dialectic actually contains, at least in one of the subjects dealt with, a very important element for the constitution of Hegel's political philosophy. We have seen that the true argument used in order to criticize slavery is the one that rests on a certain conception of human being, i.e., the one which asserts that every human being has freedom as an element of his essence. ${ }^{19}$ Therefore, when an individual does not recognize another one as his similar, he will have as the product of his behavior only a certainty about what he is, and he will not have knowledge of his true identity. Now it is time for us to discuss the cogency of Hegel's approach to the process of recognition by presenting some problems related to the use of the concept "recognition".

Our first analysis related to the process of recognition presented by Hegel in the Phenomenology of Spirit is concerned with the universe of beings that can be recognized by another being as similar to him or her, as an "other" that is posed as being as the first is. The question, therefore, can be presented in the following way: what is the purpose of establishing, as a limit to the act of recognition, the group constituted by all beings of the human species, all members of this species, and only them? We can start answering this question by analyzing the following excerpt from Phenomenology previously quoted at the beginning of this study.

The middle term is self-consciousness which splits into the extremes; and each extreme is this exchanging of its own determinateness and an absolute transition into the opposite. [...] each is for itself, and for the other, an immediate being on its own account, which at the same time is such only

\footnotetext{
${ }^{19}$ We do not ignore that Hegel, in the remark of paragraph 57 of his Philosophy of Right, actually criticizes the philosophical posture that manifests itself against the enslavement of men, and that takes into account only the universal principle that all men must be free. Indeed, in order to properly comprehend how the relation between slavery and freedom is understood, we must also verify what Hegel asserts about the slavery of each individual, specifically, and also about the behavior of such individuals. To summarize, Hegel defends the thesis that slavery is, according to the concept, something wrong, improper. Absolutely, slavery is reprovable. However, Hegel also understands that freedom must be conquered, that the individual must deserve it, and therefore he understands that the individual, the one who does nothing in order to affirm his freedom, the individual that lets himself be dominated, does not have, just by being a human being, the right to be free. Cf. Philosophy of Right, paragraph 57 and its remark. HEGEL, G. W. F. The Philosophy of Right. Translated by Alan White. Newburyport: Focus Publishing, 2002. Henceforth we will refer to this book by the abbreviation PR, followed by the number of the paragraph.
} 
through this mediation. They recognize themselves as mutually recognizing one another. ${ }^{20}$

What can be validly inferred from this description of the process of recognition is that recognition only happens when one being sees himself or herself in another being, in an "other". Recognition implies, following the quotation above, the necessary occurrence of an act of recognition of the "other" as a similar, as a being that has specific traces in common with the being who produces the comparison. The similarity, thus, is this "middle term" that produces the bond between separate beings. The relation established here is a relation which involves common features, and it is through these common features that we can, in a certain sense, state that one being and another are both one and the same being, and that consequently each one of them might obtain a knowledge about himself or herself by observing the other.

It is essential for the notion of similarity itself that when we produce a judgment of similarity between two beings, we try to indicate aspects of these beings in which they are similar; e.g., A and B are similar in weight because both have the same weight, or because the difference between them is very small. When someone produces a judgment of similarity between beings, this person necessarily disregards some aspects of these beings, and for this reason it is asserted about A and B that "regarding weight" they are similar. Thus, the observed similarity is related to the weight of both, so that the person, when making such an assertion about them, is not considering, e.g., their height, in which there might be a great difference, a great dissimilarity between them. A judgment of similarity always starts with (at least) two beings, i.e., it starts from a situation of dissimilarity. If there is at least one dissimilarity, then it is the one which makes it possible to state that there are two beings and not only one. It is based on this, then, that we make an attempt to present the similarities, the common features that exist between these two beings that, at least in one aspect, are different. We can see therefore, that even a so-called "full" recognition will always include, on a larger or smaller scale, disregarding some dissimilarities.

What Hegel asserts, as we saw, is that there is recognition when a human being recognizes all other human beings as similar to him or her. Here we have a specific judgment of similarity, with specific parameters that

${ }^{20}$ PS 184. 
can be indicated in the following way: a human being only recognizes him or herself, knows the truth about him or herself, when this human being observes all human beings as similar to him or her, and observes all beings that are not humans as dissimilar to him or her. The fact that the process of recognition is considered completed and concluded when all human beings recognize themselves as similar, leads to the consequence that all beings that are not human should not be considered similar. It involves the fact that the difference, the dissimilarity of species, is a relevant difference in opposition to, for example, the differences among social classes, which should be disregarded when the sphere of the act of recognition is decided. In other words, in this case we include all human beings, since we disregard (among other things) the distinct social classes they belong to.

When we define with these limits the sphere of attainment of recognition, we notice that there is a certain element of arbitrariness involved in Hegel's position. Previously we saw that the notion of recognition does not stipulate fixed parameters for deciding when we shall and when we shall not recognize something as similar to some other thing. The notion of "recognition" only shows a certain way of observation produced by an individual, a way in which he perceives in some beings something, an aspect, which is identical or similar to an aspect perceived in himself. The recognition described by Hegel, the one that attains between two individuals, is consequently one possible way of recognition among many others. What lacks in Hegel's text, in order for it to support his conception of recognition, is precisely the indication of an explanation of the reasons why we should only consider as valid the way of recognition that occurs according to the parameters delineated by him - i.e., only the recognition that takes into account some parameters and not other possible aspects. This lack of explanation seems to be difficult to deal with once the way we characterize the essential elements of an act of recognition is accepted. As this act will involve the identification of one or more aspects shared by two or more individuals, then in this situation recognition by itself does not determine any content for the process of recognition.

Hegel's criticism of slavery, in order to be a valid one, requires his "concept" of men to be true and justified. However, since it is not possible to determine what is the true meaning of the concept "men", and since we understand the notion of "recognition" in the way presented above, the 
argument against slavery loses its strength. ${ }^{21}$ For this reason, it ends up being valid to introduce, for example, in harmony with the model presented in the Phenomenology, the following alternatives regarding the sphere of recognition:

(1) Let us suppose it is understood that it belongs to the essence of men, and is in accordance with his concept, that he can both be a dominator and a dominated. In this case, those who in a specific moment are dominators, and in this condition recognize the other dominators as similar, can correctly assert that they possess not only a certainty, but also the truth, about what they really are. Such behavior seems to be proper once we notice the fact that such individuals assert about themselves some characteristics that they see in others like them, and these characteristics are recognized by these others in accordance with this conception.

(2) We can also conceive that the term "men" does not make reference only to those animals that belong to a certain species, according to the biological classification, but also to beings of other species that share certain abilities with human beings, for instance, the ability to feel pain. In this case the concept "men" will include all beings able to feel pain, and these beings will be able to recognize themselves and obtain knowledge about themselves (and not just certainty), only if they recognize as like them all beings who are capable of feeling pain.

Summing up the results obtained in the two parts of this study, we can now present some final considerations on the political-philosophical element contained in the dialectic of master and slave. We have seen, in the first place, that the argument presented by Hegel against slavery is the product of a combination of a certain conception of what constitutes the essence of men and an intention on the part of individuals to obtain true knowledge about themselves. It was also indicated, by quoting the Encyclopaedia, that the way Hegel conceives human beings ends up as being the basis and structural

${ }^{21}$ On the impossibility of fully determining the meaning of the concept "men", it is enough to mention that it is a term, and like any other term it has its content of meaning filled by its use. In the specific case of the term "men", the impossibility of a complete determination of its meaning is quite evident; it is enough to remember how this term was used some centuries ago in order to notice the substantial changes in the subjects that lay under this concept. Unless we postulate the existence of an "idea" of "men", what we have is only a record of the various uses of this term. With regard to the variability of the meaning of a term, it is worth remembering that Hegel is completely conscious of this aspect, as seen in the following extract: "But even if 'moral' and 'ethical' were etymologically synonymous, that would in no way hinder them, once they had become different words, from being used for different concepts". PR, $\$ 33$, remark. 
principle for the entire development of his political-philosophical project. The second part of this study had the purpose of investigating the validity of the way Hegel argued using the notions of "recognition" and "men"; it indicated that such notions were employed in an arbitrary way, since there are, in accordance with what Hegel calls a knowledge of the truth, other options equally valid for someone to say that he has a "knowledge" about himself. Indeed, what can be inferred is that the very model of the state (and also of its relations with the individuals) ends up becoming, once its basis is removed, only one model among other possible models.

SILVA, Matheus Pelegrino. Uma análise crítica sobre o elemento político-filosófico da dialética do senhor e do escravo. Trans/Form/Ação, Marília, v. 38, n. 3, p. 9-24, Set./Dez., 2015.

RESUMO: A seção "Dominação e escravidão" da Fenomenologia do espírito de Hegel nos oferece, por meio da crítica da escravidão, algumas indicaçóes com respeito à concepção hegeliana da natureza humana. Neste artigo, serão identificadas e apresentadas algumas consequências dessa concepção para a filosofia política de Hegel. A análise aponta que alguns problemas podem emergir, quando analisamos alguns dos conceitos fundamentais de Hegel, "reconhecimento" e "homem", se levamos em consideraçáo o modo como estes conceitos foram definidos na dialética do senhor e do escravo. Como resultado desses problemas, é apontado que sua filosofia política, e igualmente sua posição com respeito à escravidão, se tornam menos cogentes e mais suscetíveis a críticas. A última parte do texto analisa algumas consequências dos problemas relacionados às possibilidades de definir os conceitos "reconhecimento" e "homem" para o modelo hegeliano de Estado.

PALAVRAS-CHAVE: Hegel. Dialética do senhor e do escravo. Reconhecimento. Estado.

\section{REFERENCES}

HEGEL, G. W. F. Encyclopaedia of Philosophical Sciences. Translation by W. Wallace. Available in: < http://www.class.uidaho.edu/mickelsen/ToC/Hegel\%20-\%20Philosophy\%20of $\%$ 20Mind.htm >.

Press, 1977.

Phenomenology of spirit. Translation by A. V. Miller. Oxford: Oxford University

The Philosophy of Right. Translated by Alan White. Newburyport: Focus Publishing, 2002.

KOJÈVE, Alexandre. Introduction à la lecture de Hegel. Paris: Gallimard, 2000. 
LABARRIÈRE, Pierre-Jean; JARCZYK, Gwendoline. Les premiers combats de la reconnaissance. Paris: Aubier - Montaigne, 1987.

PINKARD, Terry. Hegel's phenomenology: the sociality of reason. Cambridge: Cambridge University Press, 1998.

VAZ, Henrique C. de Lima. Senhor e escravo: uma parábola da filosofia ocidental. Revista Sintese, s. 1., n. 21, p. 7-29, 1980.

WILLIAMS, Robert R. Regognition: Fichte and Hegel on the other. New York: State University of New York, 1992.

WOOD, Allen W. Hegel's ethical thought. Cambridge: Cambridge University Press, 1995.

Recebido / Received: 03/02/2015

Aprovado / Approved: 02/03/2015 
SILVA, M. P. 